\title{
PENGARUH RECEIVABLE TURNOVER TERHADAP RETURN ON EQUITY (ROE) PADA KOPERASI KARYAWAN SEHAT DI PT. SAMWHA INDONESIA
}

\author{
Any Yuningsih \\ STIEB Perdana Mandiri, Purwakarta, Indonesia
}

\section{Article Information}

Received: 7 Oct. 2019

Accepted: 11 Mar. 2020

Published: 18 May 2020

DOI: $10.33555 /$ ijembm.v7i1.113

Corresponding Author:

Any Yuningsih

Purwakarta, Indonesia

any.yuning@gmail.com

ISSN $\quad 2338-8854$

eISSN 2620-9918

\begin{abstract}
Employee cooperative is a type of cooperative that still survive until today because they are supported by the payment system from the members to the cooperative using salary deduction which resulted the smoothness of the receivables payment from the members to cooperative, but it still has the possibility of other problems in the financial sector. This study aimed to determine the picture of Receivable Turnover and Return on Equity (ROE) and how was the influence of the Receivable Turnover on Return on Equity (ROE) in Koperasi Karyawan Sehat. This research used a descriptive method with a quantitative approach. The data used were the secondary data from financial report of Koperasi Karyawan Sehat. The sample in this study was the balance sheet in 2010-2015. Non-probability sampling technique presented by purposive sampling was used in this study. Based on the partial hypothesis testing, there was a significant influence between accounts receivable turnover on Return on Equity (ROE), while the results of the coefficient of determination test indicate that accounts receivable turnover contributes 83, 36\% of the variable Return on Equity (ROE). The remaining of $16.64 \%$ was contributed by working capital, sales, market share, dividend policy and other factors which was not examined in this study.
\end{abstract}

Keywords: Receivable Turnover, Return on Equity (ROE), Employee Cooperative

\begin{abstract}
ABSTRAK
Koperasi karyawan adalah jenis koperasi yang masih bertahan hingga saat ini karena ditunjang oleh sistem pembayaran dari anggota ke koperasi dengan cara pemotongan gaji. Hal ini mengakibatkan adanya keamanan kelancaran pembayaran piutang dari anggota ke koperasi, namun hal ini, tidak menutup kemungkinan adanya berbagai masalah lain di bidang keuangan. Penelitian ini bertujuan untuk mengetahui gambaran Receivable Turnover dan Return on Equity (ROE) dan seberapa besar pengaruh Receivable Turnover terhadap Return on Equity (ROE) di Koperasi Karyawan Sehat. Penelitian ini menggunakan metode deskriptif dengan pendekatan kuantitatif. Data yang digunakan adalah data sekunder berupa laporan keuangan Koperasi Karyawan Sehat berupa neraca periode 2010 sampai 2015. Sampel pada penelitian ini adalah neraca tahun 2010-2015. Teknik nonprobability sampling yang disajikan dengan cara sampling purposive digunakan dalam penelitian ini.. Berdasarkan uji hipotesis secara parsial, terdapat pengaruh signifikan antara perputaran piutang terhadap Return on Equity (ROE), sedangkan hasil uji koefisien determinasi menunjukkan bahwa variabel perputaran piutang memberikan kontribusi sebesar 83,36\% terhadap variabel Return on Equity (ROE). Sisa sebesar 16,64\% merupakan kontribusi dari modal kerja, volume penjualan, pangsa pasar, kebijakan deviden dan faktor-faktor lain yang tidak diteliti dalam penelitian ini.
\end{abstract}

Keywords: Receivable Turnover, Return on Equity (ROE), Koperasi Karyawan 


\section{Pendahuluan}

Terdapat tiga kekuatan perekonomian yang saling terkait berdasarkan Pancasila dan menurut UUD 1945 yaitu Badan Usaha Milik Negara (BUMN), swasta dan koperasi. UUD 1945 pasal 33 ayat 1 menyatakan bahwa "perekonomian Indonesia disusun sebagai usaha bersama berlandaskan asas kekeluar-gaan dan tidak mengutamakan kemakmuran perorangan". Bangunan yang sesuai dengan pernyataan tersebut di atas adalah koperasi. Koperasi sebagai salah satu sektor kekuatan perekonomian Indonesia diharapkan dapat menjadi tombak perekonomian Indonesia.

Sebagai salah satu bentuk pertanggungjawaban, koperasi wajib menyusun laporan keuangan yang dapat digunakan untuk pengambilan keputusan, perencanaan dan pengendalian koperasi. Laporan keuangan koperasi memiliki perbedaan dengan laporan keuangan badan usaha lainnya. Terdapat perbedaan istilah antara lain laporan promosi ekonomi anggota. Laporan Laba Rugi pada koperasi disebut Laporan Perhitungan Sisa Hasil Usaha. Akun-akun lain yaitu Piutang, Pendapatan dan Kewajiban harus dibedakan antara transaksi antar anggota maupun non anggota.

Ikatan Akuntan Indonesia (IAI) mengeluarkan standar khusus bagi koperasi mengenai Pernyataan Standar Akuntansi Keuangan (PSAK) No. 27 tentang seluruh aturan badan usaha koperasi yanng meliputi konsep dasar dan bentuk penyajian laporan keuangan. Catatan atas Laporan Keuangan Koperasi merupakan bagian yang tidak terpisahkan dari penyajian laporan keuangan. Di mana laporan keuangan digunakan untuk memberikan informasi tambahan tentang pos-pos Neraca serta Perhitungan Sisa Hasil Usaha. Catatan atas laporan keuangan menampilkan akun-tansi dan informasi lain yang berhubungan dengan laporan keuangan koperasi.
Sayangnya, peran koperasi terhadap ekonomi Indonesia justru semakin memburuk. Menurut catatan Kementerian Koperasi dan UKM, saat ini jumlah koperasi di Indonesia mencapai 209.488 unit. Dari jumlah tersebut, terdapat 147.249 unit yang masih aktif, sementara 62.239 unit sisanya tidak lagi beroperasi dan telah dikeluarkan dari database kementerian (sumber: Liputan6 by Nurmayanti on 15 Feb 2016). Jumlah koperasi tidak aktif di Indonesia saat ini telah mengalami penurunan sebesar 13.000 koperasi. Menurut Deputi Bidang Kelembagaan Kementerian Koperasi dan Usaha Kecil Menengah, dari total 62.000 koperasi yang nonaktif, jumlah ini turun menjadi 49.000. Diperkirakan jumlah tersebut merupakan koperasi yang dinilai tidak aktif dan bangkit kembali setelah melakukan revitalisasi, restrukturisasi, serta penataan kembali organisasi (sumber: okezone.com by Deddy Afrianto, Kamis 03 Maret 2016).

Kinerja perusahaan tidak hanya berdasarkan kepada aspek keuangan, namun juga mempertimbangkan aspek-aspek non keuangan lain yang sangat penting guna mengetahui kinerja yang sesungguhnya telah dicapai perusahaan. Pengelolaan manajemen yang baik akan menjadi salah satu kunci sukses keberhasilan perusahaan untuk tetap bertahan di kondisi sekarang ini. Pengelolaan sumber daya yang ada yang efektif dan efisien akan mampu memaksimalkan hasil yang dicapai sesuai dengan tujuan perusahaan yaitu memperoleh keuntungan yang maksimal. Dengan keuntungan yang maksimal, perusahaan dapat melakukan banyak hal bagi kesejahteraan pemilik perusahaan, karyawan, meningkatkan mutu produk serta melakukan investasi baru. Oleh karena itu, manajemen perusahaan dituntut untuk mampu memenuhi target keuntungan yang telah ditetapkan sebelumnya.

Menurut Harjito dan Martono (2012) profitabilitas adalah rasio yang menam- 
pilkan kemampuan perusahaan dalam memperoleh laba dari perputaran modal yang dimilikinya. Penelitian ini menggunakan profitabilitas yang mengukur kemampuan perusahaan dalam menghasilkan keuntungan dari modal yang dimiliki perusahaan. Jenis-jenis rasio untuk mengukur profitabilitas diantaranya profit margin, Return on Investment (ROI), Return on Equity (ROE), dan laba per lembar saham" (Kasmir, 2014). Untuk mendapatkan laba diperlukan sumbersumber dana bagi perusahaan dan mengoptimalkan secara efektif dan efisien. Menurut Sutrisno (2013) Return on Equity (ROE) yaitu "kemampuan perusahaan dalam menghasilkan keuntungan dengan modal sendiri yang dimiliki, sehingga ROE ini ada yang menyebut sebagai rentabilitas modal sendiri". Menurut Husnan dan Pudjiastuti (2012) Return on Equity (ROE) merupakan "rasio untuk mengukur seberapa banyak keuntungan yang menjadi hak pemilik modal sendiri".

Salah satu faktor yang mempengaruhi tingkat profitabilitas adalah modal kerja yang komponen di dalamnya terdiri dari kas, kas dan persediaan. Untuk mengetahui tingkat efektivitas dari salah satu komponen modal kerja tersebut yaitu piutang, dapat diukur dari tingkat perputarannya. Masa perputaran modal kerja menunjukkan efisiensi penggunaan modal kerja. Semakin cepat perputaran modal kerja maka akan semakin efisien pula penggunaannya sehingga investasi pada modal kerja akan menjadi semakin kecil.

Semakin tingginya tingkat persaingan antar perusahaan akan membuat perusahaan dapat memberikan pelayanan maksimal kepada pelanggannya termasuk memberikan kemudahan dalam pembayaran piutang sehingga penjualan secara kredit menjadi suatu alternatif bagi perusahaan dalam rangka untuk meningkatkan penjualannya. Dari transaksi penjualan secara kredit akan muncul piutang dagang, terhadap transaksi ini perusahaan wajib menyisihkan dana yang akan diinvestasikan ke dalam piutang tersebut.

Koperasi karyawan termasuk jenis koperasi yang masih bertahan hingga saat ini karena ditunjang oleh sistem pembayaran anggota dengan cara pemotongan gaji, sehingga menjamin keamanan kelancaran pembayaran piutang anggota, namun tidak menutup kemungkinan terdapat berbagai masalah lain di bidang keuangan.

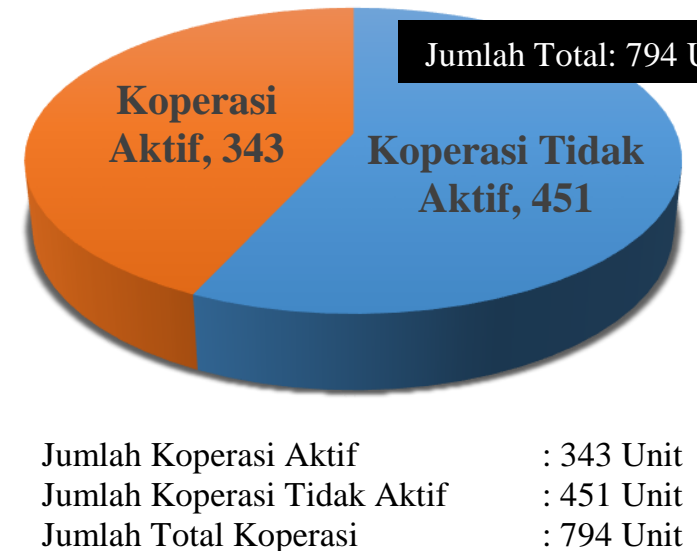

Gambar 1. Gambaran Jumlah Koperasi Kabupaten Purwakarta

Sumber: https google.com/jabarcyberkoperasi.com/data-koperasi-jawa-barat /our-company/kabupaten-purwakarta://sites 
Dari hasil penelitian yang telah dilakukan sebelumnya terdapat inkonsistensi hasil penelitian. Penelitian Luh Komang Suarnami, I Wayan Suwendra, Wayan Cipta (2014) dalam jurnal yang berjudul" Pengaruh Perputaran Piutang dan Periode Pengumpulan Piutang Terhadap Profitabilitas pada Perusahaan Pembiayaan" menunjukkan bahwa perputaran piutang tidak berpengaruh besar terhadap Profitabilitas.

Menurut Yuli Nopiana, Nyoman Trisna Herawati, Ni Luh Gede Erni Sulindawati (2015) dalam artikel yang berjudul "Pengaruh Tingkat Perputaran Modal Kerja, Perputaran Kas, Perputaran Piutang, Pertumbuhan Jumlah Nasabah, dan Jumlah Karyawan Terhadap Profitabilitas Koperasi Simpan Pinjam di Kabupaten Buleleng" menunjukkan bahwa tingkat perputaran piutang berpengaruh kepada profitabilitas Koperasi Simpan Pinjam di Kabupaten Buleleng periode 2012-2014. Berdasarkan hasil uji t yang menunjukkan bahwa nilai thitung sebesar 4,243 dengan nilai signifikan $0,000 \leq \alpha=0,05$. Hal ini membuktikan bahwa semakin tinggi tingkat perputaran piutang maka profitabilitas Koperasi Simpan Pinjam (KSP) akan semakin meningkat. Berdasarkan paparan di atas, peneliti akan membahas: "Pengaruh Receivable Turnover Terhadap Return on Equity (ROE) pada Koperasi Karyawan Sehat di PT. SAMWHA Indonesia" yang mempunyai badan hukum no: 11204/BH/PAD/KDK.10.10 /VII/1999 tanggal 14 Juli 1999.

Berdasarkan latar belakang tersebut, maka penulis merumuskan beberapa permasalahan sebagai berikut:

a. Bagaimana gambaran Receivable Turnover pada koperasi karyawan Sehat Purwakarta?

b. Bagaimana gambaran Return on Equity (ROE) pada koperasi karyawan Sehat Purwakarta?

c. Bagaimana pengaruh Receivable Turnover terhadap Return on Equity (ROE) kepada koperasi karyawan Sehat Purwakarta?

\section{Tinjauan Pustaka}

\subsection{Manajemen Keuangan}

Manajemen keuangan (financial management) menurut Harjito dan Martono (2011) merupakan "segala aktivitas perusahaan yang berhubungan dengan bagaimana memperoleh dana, menggunakan dana, dan mengelola aset sesuai tujuan perusahaan secara menyeluruh". Menurut Sutrisno (2013), "manajemen keuangan adalah semua aktivitas perusahaan yang berhubungan dengan usaha-usaha mendapatkan dana perusahaan dengan biaya yang murah serta usaha untuk menggunakan dan mengalokasikan dana tersebut secara efisien".

\subsection{Manajemen Koperasi}

Koperasi dibangun guna mengangkat masyarakat dari kesulitan dan kemiskinan. Hal ini berkaitan dengan pola pengaturan kelembagaan masyarakat dalam membangun kesejahteraan secara bersama-sama. Guna mencapai tujuan tersebut, maka koperasi harus mandiri. Ciri-ciri koperasi menurut Undang Undang nomor 12 Tahun 1967 tentang Pokok Pokok Perkoperasia "kekuatan tertinggi terdapat pada rapat anggota, satu anggota satu suara, koperasi mengutamakan pelajaran dan melakukan pendidikan bagi anggota, serta manajemen untuk meningkatkan kesejahteraan". Faktor-faktor efektifitas dan efesiensi usaha koperasi antara lain yaitu efesiensi proses usaha, loyalitas anggota, penawaran yang cukup, persaingan, dan harga eceran sehingga perbedaan harga eceran koperasi dengan eceran di pasar merupakan salah satu sumber koperasi guna meningkatkan simpanan anggota di koperasi. Manajemen koperasi adalah seluruh bentuk kegiatan yang perlu dilakukan guna menyatukan masyarakat yang mempunyai kepentingan yang sama. Proses manajemen dalam pengembangan 
koperasi menurut pasal 33 Undang Undang 1945 yaitu:

a. "Perekonomian disusun sebagai usaha bersama berdasarkan atas asas kekeluargaan.

b. Cabang cabang produksi yang penting bagi negara yang mengusai hajad hidup orang banyak dikuasai negara.

c. Bumi, air dan kekayaan alam yang terkantung di dalamnya dikuasai oleh negara dan dipergunakan untuk sebesar-besar kemakmuran rakyat."

Dalam kerangka proses manajemen, yang dimaksud dengan perencanaan jangka panjang adalah keputusan mengenai sarana yang akan dicapai serta perumusan yang nyata.

\subsection{Penerapan Akuntansi pada Laporan Keuangan di Koperasi}

Laporan keuangan koperasi merupakan laporan pertanggungjawaban kegiatan usaha koperasi kepada pihak luar yang berhubungan dengan koperasi baik sebagai anggota koperasi maupun sebagai kreditur. Laporan Keuangan koperasi terdiri dari:

a. Laporan perhitungan hasil usaha Menyajikan jumlah pendapatan usaha koperasi yang berasal dari anggota maupun non anggota dengan membandingkan total biaya dalam satu periode tertentu. Laporan keuangan ini serupa dengan laporan laba/rugi di perusahaan bukan koperasi.

b. Neraca

Laporan keuangan yang menyajikan posisi harta, hutang, dan modal koperasi pada suatu periode pembukuan tertentu, umumnya satu tahun. Di dalamnya terdapat jumlah dan sumber dana serta beberapa pos alokasi sumber dana guna memberikan informasi kepada pihak-pihak yang berkepentingan dengan laporan keuangan perusahaan (koperasi) tersebut. c. Laporan arus kas

Menampilkan informasi perubahan kas yang meliputi saldo awal kas, sumber penerimaan kas, pengeluaran kas, dan saldo akhir kas pada suatu periode tertentu.

d. Laporan promosi ekonomi anggota

\subsection{Manajemen Piutang}

Laporan yang menyajikan manfaat yang diperoleh anggota koperasi selama satu tahun dan menggambarkan pencapaian tujuan koperasi. Hal ini harus dipahami oleh semua yang terlibat di dalam dan di luar koperasi, agar koperasi dapat ditempatkan pada posisi yang tepat dan tidak disalahtafsirkan dalam evaluasi kerjanya.

Pengertian piutang (receivable) menurut Sutrisno (2013) adalah "tagihan perusahaan kepada pihak lain sebagai akibat penjualan secara kredit". Kasmir (2011), menyatakan bahwa terdapat 3 tujuan piutang yaitu:

a. Meningkatkan penjualan

Meningkatkan penjualan dapat diartikan agar omzet penjualan meningkat atau bertambah dari waktu ke waktu. Dengan penjualan kredit diharapkan penjualan dapat meningkat mengingat sebagian besar pelanggan kemungkinan tidak mampu membeli secara tunai.

b. Meningkatkan laba

Meningkatkan penjualan tidak identik dengan meningkatkan laba atau keuntungan. Namun dalam praktiknya, apabila penjualan meningkat mqkq kemungkinan besar laba akan meningkat pula. Hal ini dapat terlihat dari omzer penjualan yang dimilikinya. Sehingga dengan memberikan kebijakan penjualan secara kredit akan mampu meningkatkan penjualan sekaligus keuntungan.

c. Menjaga loyalitas pelanggan 
Tidak selamanya pelanggan memiliki dana tunai untuk membeli barang dengan alasan tertentu sehingga jika dipaksakan, pelanggan tidak akan membeli produk kita, bahkan mungkin akan berpindah ke perusahaan lain. Untuk mempertahankan pelanggan, perusahaan dapat memberikan pelayanan kredit.

Faktor-faktor yang mempengaruhi besar kecilnya persediaan piutang, menurut Sutrisno (2013) adalah :

a. Volume penjualan kredit

Semakin besar penjualan kredit maka akan semakin besar pula jumlah piutang dan sebaliknya.

b. Syarat pembayaran bagi penjualan kredit.

Semakin panjang batas waktu pembayaran semakin besar pula jumlah piutang dan sebaliknya.

c. Ketentuan tentang batas volume penjualan kredit.

Jika batas maksimal penjualan kredit ditetapkan dalam jumlah besar maka piutang akan semakin besar.

d. Kebiasaan membayar para pelanggan kredit.

Jika kebiasaan membayar pelanggan mundur dari waktu yang telah ditetapkan maka piutang akan semakin besar.

e. Kegiatan penagihan piutang dari pihak perusahaan.

Bila penagihan piutang bersifat aktif maka jumlah piutang semakin kecil dan jika pasif maka jumlah piutang akan semakin besar.

\subsection{Receivable Turnover (Perputaran Piutang)}

Tingkat receivable turnover dapat diketahui dengan cara membagi jumlah credit sales selama periode tertentu dengan jumlah rata-rata piutang (average receivable). Semakin mudah syarat pembayarannya maka akan semakin lama modal tersebut terikat dalam piutang. Hal ini berarti tingkat perputarannya semakin rendah. Menurut Kasmir (2011), perputaran piutang adalah rasio yang digunakan untuk mengukur berapa lama penagihan piutang selama satu periode.

\subsection{Rasio Keuangan}

Menurut Munawir (2014), rasio keuangan merupakan gambaran suatu hubungan antara jumlah tertentu dengan jumlah yang lain. Dengan menggunakan rasio ini, dapat dijelaskan tentang baik buruknya posisi keuangan perusahaan terutama jika angka rasio tersebut dibandingkan dengan angka rasio lain yang digunakan sebagai standar. Menurut Harjito dan Martono (2011) terdapat 6 jenis rasio yang dapat digunakan guna menilai kinerja keuangan perusahaan yaitu:

a. Rasio likuiditas (liquidity ratio) yang digunakan untuk mengukur kemampuan perusahaan dalam memenuhi beberapa kewajiban finansialnya.

b. Rasio aktivitas (activity ratio) yang digunakan guna mengukur efisiensi perusahaan dalam menggunakan asetasetnya.

c. Rasio leverage financial (financial leverage ratio) yang digunakan untuk mengukur seberapa banyak perusahaan tersebut menggunakan dana dari hutang (pinjaman).

d. Rasio keuntungan (profitability ratio) digunakan untuk mengukur kemampuan perusahaan dalam memperoleh keuntungan dari penggunaan modalnya.

e. Rasio investasi (investment ratio) menunjukkan rasio investasi dalam surat berharga, saham dan obligasi.

f. Rasio nilai pasar menggambarkan kondisi yang terjadi di pasar yang menjelaskan kepada pihak manajemen perusahaan mengenai kondisi penerapan yang akan dilaksanakan dan dampaknya di masa mendatang. 
Perusahaan yang dikategorikan memiliki kinerja yang baik dapat diukur dengan melihat kemampuan perusahaan dalam memenuhi kewajiban (hutang) yang akan jatuh tempo (liquidity), menyusun struktur pendanaan berupa perbandingan antara utang dan modal (leverage), memperoleh keuntungan (profitability), untuk berkembang (growth), dan dalam mengelola aset yang dimiliki secara maksimal (activity) (Sugiono, 2009).

\subsection{Rasio Profitabilitas}

Rasio profitabilitas menurut Fahmi (2014) merupakan "rasio yang mengukur efektivitas manajemen secara keseluruhan yang ditujukan oleh besar kecilnya tingkat keuntungan yang diperoleh dalam hubungannya dengan penjualan maupun investasi". Menurut Harjito dan Martono (2011) rasio profitabilitas terdiri dari dua jenis yaitu:

1. Profitabilitas antara penjualan dengan laba yang dapat dibedakan sebagai berikut:

a. Gross Profit Margin (GPM), merupakan rasio antara laba kotor dengan penjualan bersih.

b. Net Profit Margin (NPM). Margin ini menujukkan perbandingan laba bersih setelah pajak dengan penjualan.

2. Profitabilitas dalam hubungannya antara laba dengan investasi yaitu:

a. Return on Investment (ROI) membandingkan laba setelah pajak dengan total aktiva.

b. Return on Equity (ROE) untuk mengukur seberapa banyak keuntungan yang menjadi hak pemilik modal.

c. Rentabilitas Ekonomi untuk mengukur kemampuan dalam memperoleh laba usaha dengan aktiva yang digunakan.
Menurut Kasmir (2014), tujuan penggunaan rasio profitabilitas bagi perusahaan dan bagi pihak luar perusahaan yaitu:

a. Untuk mengukur laba yang diperoleh perusahaan dalam periode tertentu.

b. Untuk menilai posisi laba perusahaan tahun sebelumnya dengan tahun berjalan.

c. Untuk menilai perkembangan laba dalam periode tertentu.

d. Untuk menilai besaran laba bersih setelah dikurangi pajak dengan modal yang dimiliki.

e. Untuk mengukur produktivitas seluruh dana perusahaan yang digunakan baik modal pinjaman maupun modal yang dimiliki.

f. Untuk mengukur produktivitas dari seluruh dana yang dimiliki oleh sebuah perusahaan.

\subsection{Return on Equity (ROE)}

Menurut Kasmir (2014) Return on Equity adalah "rasio untuk mengukur laba bersih sesudah pajak dengan modal sendiri" yang menunjukkan efisiensi penggunaan modal yang dimiliki. Semakin tinggi rasio berarti posisi pemilik perusahaan akan semakin kuat dan sebaliknya.

Rumus Return on Equity (ROE) menurut Hanafi dan Halim (2012):

$$
\text { Return on Equity }(R O E)=\frac{\text { Laba Bersih }}{\text { Modal saham }}
$$

\subsection{Kerangka Pemikiran}

Menurut Harjito dan Martono (2011) Return on Equity (ROE) digunakan untuk mengukur seberapa banyak keuntungan yang menjadi hak pemilik modal". Sebuah perusahaan harus memiliki manajemen keuangan yang baik karena dapat menggambarkan kinerja perusahaan itu sendiri terutama kemampuan perusahaan dalam menghasilkan keuntungan terhadap faktor-faktor yang mempengaruhi perolehan keuntungan tersebut. Salah satunya 
adalah modal kerja yang indikatornya adalah kas, piutang dan persediaan. Perputaran piutang merupakan indikator terhadap perolehan keuntungan karena semakin tinggi tingkat perputarannya maka akan semakin baik pula perolehan keuntungan bagi perusahaan, di mana untuk mengukur keuntungan tersebut gambaran terhadap objek yang diteliti melalui data atau sampel yang telah dikumpulkan tanpa melakukan analisis menggunakan rasio keuntungan (profitability ratio) dan profitabilitas yang digunakan adalah ROE (Return on Equity).

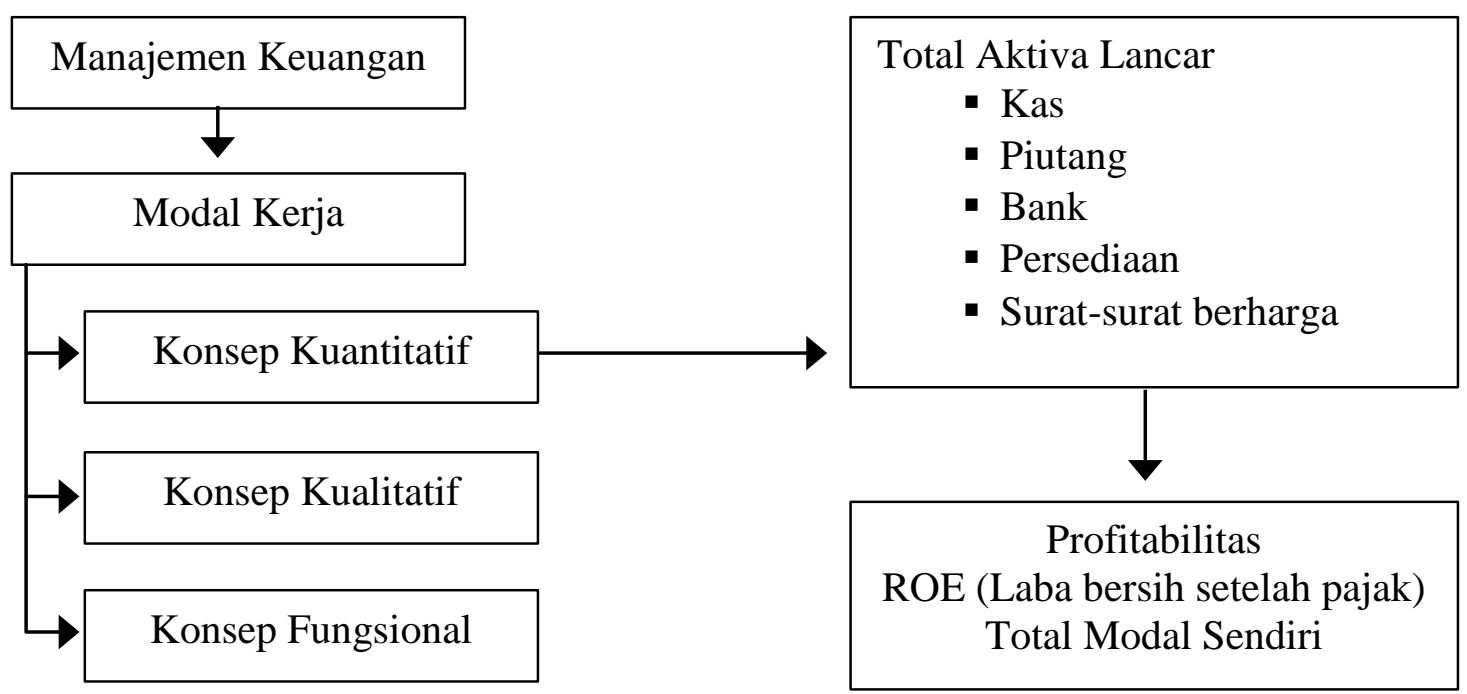

Gambar 2. Kerangka Pemikiran

Sumber: Agus Harjito dan Martono (2011)

Berdasarkan gambar 2 dapat dijelaskan bahwa peneliti menggunakan konsep kuantitatif yang elemen-elemennya meliputi: kas, piutang, bank, persediaan, dan surat-surat berharga. Berdasarkan kerangka pemikiran tersebut, dapat dibuat gambaran penelitian sebagai berikut:

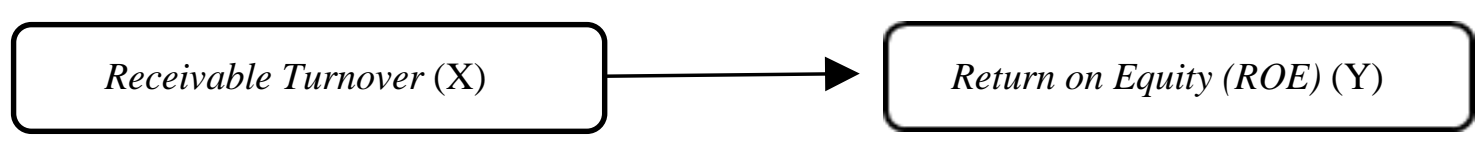

Gambar 3. Gambaran Penelitian

Gambar 3 di atas menjelaskan gambaran hubungan antara variabel bebas (X) dengan variabel terikat (Y). Pengaruh variable receivable turnover $(\mathrm{X})$ terhadap Return on Equity (ROE) (Y).

\section{Metode Penelitian}

Penelitian ini menggunakan metode penelitian deskriptif, menurut Sugiyono (2014), metode deskriptif adalah metode yang digunakan untuk mendeskripsikan dan membuat kesimpulan yang berlaku umum. Melalui jenis penelitian deskriptif, maka dapat diperoleh deskripsi mengenai:

a. Gambaran receivable turnover di Koperasi Karyawan Sehat.

b. Gambaran Return on Equity (ROE) di Koperasi Karyawan Sehat.

Penelitian ini menggunakan pendekatan kuantitatif yang dilakukan dengan mengumpulkan data berupa angka dan 
diolah untuk mendapatkan informasi ilmiah di balik angka-angka tersebut (Martono, 2012).

Dalam penelitian ini terdapat hubungan antara variabel di mana perputaran piutang berpengaruh terhadap Return on Equity (ROE), sehingga dari hubungan tersebut diperoleh variabel bebas dan variabel terikat.

a. Variabel bebas atau independen variable menurut Sugiono (2014) adalah "variabel yang mempengaruhi atau yang menjadi sebab perubahan atau timbulnya variabel dependen (variabel terikat)". Dalam penelitian ini yang menjadi variabel bebas adalah receivable turnover (perputaran piutang).

b. Variabel terikat merupakan "variabel yang dipengaruhi atau yang menjadi akibat, karena adanya variabel bebas" (Sugiyono, 2014). Dalam penelitian ini yang menjadi variabel terikat yaitu Return on Equity (ROE).

Jenis data pada penelitian ini adalah jenis data sekunder, berupa laporan keuangan Koperasi Karyawan Sehat berupa neraca periode 2010 hingga tahun 2015. Sampel pada penelitian ini adalah neraca tahun 2010-2015. Teknik yang digunakan dalam penelitian ini adalah teknik nonprobability sampling yang disajikan dengan cara sampling purposive. Menurut Martono (2012) "Sampling Purposive merupakan teknik penentuan sampel dengan pertimbangan tertentu".

\section{Hasil dan Diskusi}

\subsection{Receivable Turnover (Perputaran Piutang)}

Berdasarkan hasil perhitungan tingkat perputaran pada tabel 1 di bawah ini, diketahui bahwa rata-rata tingkat receivable turnover tertinggi dialami pada saat tahun 2010 dengan rata-rata 0.31 kali. Pada tahun selanjutnya terus mengalami penurunan sampai dengan 2015. Ini berarti dalam siklus normal atau dalam satu tahun terjadi receivable turnover (perputaran piutang) paling tinggi sebanyak 31 kali atau setiap 12 hari adanya pemasukan kas, dan perputaran piutang paling rendah sebanyak 21 kali. Semakin tinggi receivable turnover suatu perusahaan semakin baik dan sebaliknya. Receivable turnover dapat ditingkatkan dengan cara memperketat kebijakan pemberian kredit.

Tabel 1. Receivable turnover Koperasi Karyawan Sehat Periode Tahun 2010-2015 Sumber: Laporan keuangan Koperasi Karyawan Sehat

\begin{tabular}{ccccc}
\hline No. & Tahun & Total Pendapatan & Rata-Rata Piutang & Receivable Turnover \\
\hline 1 & 2010 & Rp. $413,700,192.55$ & Rp. 1,324,055,085.58 & 0.31 kali \\
\hline 2 & 2011 & Rp. $469,733,310.69$ & Rp. 1,549,638,260.20 & 0.30 kali \\
\hline 3 & 2012 & Rp. 529,917,491.98 & Rp. 1,840,754,897.70 & 0.29 kali \\
\hline 4 & 2013 & Rp. 533,604,767.00 & Rp. 2,047,491,185.20 & 0.26 kali \\
\hline 5 & 2014 & Rp. 524,968,837.00 & Rp. 2,273,149,343.70 & 0.23 kali \\
\hline 6 & 2015 & Rp. 556,000,781.62 & Rp. 2,635,322,615.70 & 0.21 kali \\
\hline
\end{tabular}




\subsection{Return on Equity (ROE)}

Berdasarkan tabel 2 di bawah dapat dilihat bahwa semakin tinggi return atau penghasilan yang diperoleh semakin baik kedudukan atau posisi pemilik perusahaan atau koperasi dan sebaliknya.
Tingkat ROE tertinggi terjadi pada tahun 2010 sebesar $20.00 \%$ dan tingkat ROE terendah dialami Koperasi Karyawan Sehat pada tahun 2015 yaitu sebesar $14.03 \%$. Dari tahun ke tahun rasio turun sekitar 1-3\%.

Tabel 2. Return on Equity (ROE) Koperasi Karyawan Sehat Periode Tahun 2010-2015 Sumber : Laporan keuangan Koperasi Karyawan Sehat

\begin{tabular}{ccccc}
\hline No. & Tahun & Laba Bersih & Modal Sendiri & ROE \\
\hline 1 & 2010 & Rp. $261,331,485.05$ & Rp. 1,283,773,409.02 & $20 \%$ \\
\hline 2 & 2011 & Rp. $266,619,566.69$ & Rp. $1,524,703,773.27$ & $17 \%$ \\
\hline 3 & 2012 & Rp. 339,818,483.98 & Rp. 1,760,085,034.09 & $19 \%$ \\
\hline 4 & 2013 & Rp. 353,079,446.97 & Rp. 2,219,963,064.18 & $16 \%$ \\
\hline 5 & 2014 & Rp. 345,442,689.00 & Rp. 2,363,513,236.33 & $15 \%$ \\
\hline 6 & 2015 & Rp. 363,304,854.34 & Rp. 2,590,149,699.04 & $14 \%$ \\
\hline
\end{tabular}

\subsection{Perbandingan Receivable Turnover dan Return on Equity (ROE)}

Berdasarkan tabel 3 di bawah, tingkat receivable turnover mengalami penurunan setiap tahunnya dengan tingkat tertinggi yaitu 0.31 kali pada tahun 2010 dan tingkat terendah 0.21 kali pada tahun 2015. Begitu pula dengan ROE mengalami penurunan setiap tahunnya dengan dengan tingkat ROE tertinggi $20 \%$ pada tahun 2010 dan tingkat terendah $14 \%$ pada tahun 2015.

Tabel 3. Perbandingan Receivable Turnover Dan Return on Equity (ROE)

\begin{tabular}{ccccccccc}
\hline \multirow{2}{*}{ No. Keterangan } & \multicolumn{7}{c}{ Tahun } \\
\cline { 2 - 8 } & & $\mathbf{2 0 1 0}$ & $\mathbf{2 0 1 1}$ & $\mathbf{2 0 1 2}$ & $\mathbf{2 0 1 3}$ & $\mathbf{2 0 1 4}$ & $\mathbf{2 0 1 5}$ & Ket. \\
\hline $\begin{array}{l}\text { Receivable } \\
\text { Turnover }\end{array}$ & $0.31 \mathrm{kali}$ & $0.30 \mathrm{kali}$ & $0.29 \mathrm{kali}$ & $0.26 \mathrm{kali}$ & $0.23 \mathrm{kali}$ & $0.21 \mathrm{kali}$ & Turun \\
\hline 2 & ROE & $20 \%$ & $17 \%$ & $19 \%$ & $16 \%$ & $15 \%$ & $14 \%$ & Turun \\
\hline
\end{tabular}


Tabel 4. Rekapitulasi Hasil Analisis Receivable Turnover Piutang Terhadap Return on Equity (ROE) Sumber: Hasil pengolahan data 2016

\begin{tabular}{|c|c|c|c|}
\hline No. & Analisis & Keterangan & Hasil \\
\hline 1. & $\begin{array}{l}\text { Uji Korelasi } \\
\text { Product } \\
\text { Moment }\end{array}$ & $\begin{array}{l}\text { Nilai } r=0,913, \\
\text { dan nilai sig } 0,011\end{array}$ & $\begin{array}{l}\text { Diperoleh nilai koefisien korelasi yang positif yaitu sebesar } 0,341 . \\
\text { Nilai } 0,913 \text { (berada diantara } 0,80-1,000 \text { pada tabel interpretasi } \\
\text { koefisien korelasi) Dengan demikian, menunjukkan terdapat } \\
\text { hubungan yang sangat kuat antara receivable turover dengan } \\
\text { Return on Equity (ROE). }\end{array}$ \\
\hline 2. & $\begin{array}{l}\text { Uji Regresi } \\
\text { Sederhana }\end{array}$ & $\begin{array}{l}\text { Receivable } \\
\text { Turnover }=0,525\end{array}$ & $\begin{array}{l}\text { Koefisien regresi receivable turnover sebesar dan bertanda positif, } \\
\text { artinya setiap perubahan satu satuan pada receivable turnover, } \\
\text { maka perubahan Return on Equity (ROE) akan mengalami } \\
\text { perubahan sebesar } 0,525 \text { dengan arah yang sama. }\end{array}$ \\
\hline 3. & $\mathrm{Uji} \mathrm{t}$ & $\begin{array}{l}\text { thitung } \geq \text { ttabel } \\
4,485 \geq 2,776 \\
\text { Artinya: } \\
\text { Signifikan }\end{array}$ & $\begin{array}{l}\text { Receivable turnover diperoleh thitung sebesar } 4,485 \text { dan ttabel } \\
\text { sebesar } 2,776 \text { atau } 4,485 \geq 2,776 \text { yang artinya Ho ditolak, dengan } \\
\text { kata lain bahwa terdapat pengaruh yang signifikan antara } \\
\text { receivable turnover dengan Return on Equity }(R O E) \text {. }\end{array}$ \\
\hline 4. & $\begin{array}{l}\text { Uji Koefisien } \\
\text { Determinasi }\end{array}$ & $\mathrm{R} 2=0,834$ & $\begin{array}{l}\text { Perolehan nilai koefisien determinasi adalah sebesar } 0,834 \text { atau } \\
\text { sebesar } 83,36 \% \text { yang artinya variabel receivable turnover } \\
\text { memberikan kontribusi sebesar } 83,36 \% \text { terhadap variabel retrun on } \\
\text { equity }(R O E) \text {. }\end{array}$ \\
\hline
\end{tabular}

\section{Kesimpulan}

Berdasarkan pembahasan di atas, maka dapat diambil kesimpulan dari penelitian mengenai pengaruh receivable turnover terhadap Return on Equity (ROE) pada Koperasi Karyawan Sehat di PT. SAMWHA Indonesia adalah sebagai berikut:

a. Gambaran perputaran piutang pada Koperasi Karyawan Sehat periode 2010-2015 mengalami fluktuasi. dalam siklus normal atau dalam satu tahun terjadi receivable turnover (perputaran piutang) paling tinggi sebanyak 31 kali atau setiap 12 hari adanya pemasukan kas, dan perputaran piutang paling rendah sebanyak 21 kali. Semakin tinggi receivable turnover suatu perusahaan semakin baik, begitu juga sebaliknya. Receivable turnover dapat ditingkatkan dengan cara memperketat kebijakan pemberian kredit.

b. Gambaran Return on Equity (ROE) pada Koperasi Karyawan Sehat periode
2010-2015 mengalami fluktuasi. Dari tahun ke tahun rasio turun sekitar 1$3 \%$. Semakin tinggi return atau penghasilan yang diperoleh semakin baik kedudukan atau posisi pemilik perusahaan atau koperasi dan sebaliknya.

c. Hasil uji hipotesis secara parsial menunjukkan bahwa nilai sig $<0,05$ atau $0,011<0,05$. Artinya Ho ditolak, dengan kata lain terdapat pengaruh yang signifikan antara perputaran piutang terhadap Return on Equity (ROE). Sedangkan hasil uji koefisien determinasi adalah sebesar 0,834 atau sebesar 83,36\%. Artinya variabel perputaran piutang memberikan kontribusi sebesar 83,36\% terhadap variabel Return on Equity (ROE), sedangkan sisanya sebesar $16,64 \%$ merupakan kontribusi dari modal kerja, volume penjualan, pangsa pasar, kebijakan deviden dan faktor-faktor lain yang tidak diteliti dalam penelitian ini. 


\section{Daftar Pustaka}

Fahmi, I. (2012). Analisis Kinerja Keuangan. Bandung: Alfabeta.

Hanafi, M., Mamduh. \& Halim, A. (2009). Analisis Laporan Keuangan. Yogyakarta: UPP STIM YPKP.

Harjito, A., \& Martono. (2011). Manajemen Keuangan. 2nd Ed. Yogyakarta: Ekonisia.

Husnan. \& Pudjiastuti, E. (2012). Manajemen Keuangan. 6th Ed. Jakarta: UPP STIM YKPN.

Kasmir. (2014). Analisis Laporan Keuangan. Jakarta: Rajawali Pers.

Martono \& Agus. (2010). Manajemen Keuangan. 3rd Ed.. Yogyakarta: Ekonisia.

Martono, N. (2012). Metode Penelitian Kuantitatif: Analisis Isi dan Analisis Data Sekunder. Jakarta: Raja Grafindo Persada.

Munawir. (2014). Analisis Laporan Keuangan. Yogyakarta: Liberty.

Sugiyono. (2012). Metode Penelitian Bisnis. CV. Alfabeta, Bandung.

Sutrisno, E. (2013). Manajemen Sumber Daya Manusia. 1st Ed. Jakarta: Kencana. 